\title{
A study of seasonally delayed puberty in the male hare, Lepus europaeus
}

\author{
G. A. Lincoln and Pamela C. B. MacKinnon* \\ M.R.C. Unit of Reproductive Biology, 2 Forrest Road, Edinburgh EH1 $2 Q W$, and \\ *University of Oxford, Department of Human Anatomy, South Parks Road, Oxford OX1 3QX, U.K.
}

\begin{abstract}
Summary. The brown hare, Lepus europaeus, has a mating season which extends from January to September. Adult males exhibit pronounced seasonal changes in the reproductive tract which are associated with changes in $\mathrm{LH}$ secretion. Maximum plasma levels of immunoreactive LH occur between March and June and minimal levels in the autumn non-mating period from September to December; this seasonal cycle in gonadotrophin output is reflected by the appropriate changes in the secretion of testosterone from the testes and in the activity of the accessory sex glands. Juvenile animals reach puberty only during the adult mating season, and the age of puberty thus varies with the date of birth. Males born before May reach puberty and become fertile at 3 months of age, while those born from May to July grow to a mature body size during the autumn non-mating season but puberty is delayed for several months. Since some animals experiencing delayed puberty were found to have elevated plasma levels of $\mathrm{LH}$ and testosterone, it is concluded that puberty is not completely suppressed by the environmental effects of the autumn, but that the developmental process is prolonged, resulting in the juveniles being synchronized with the adults in their reproductive activity.
\end{abstract}

\section{Introduction}

Mammals that have a clearly defined mating season usually attain puberty during the period of reproductive activity amongst the adults. In Scotland, for example, male red deer, Cervus elaphus, are born mostly in June, and first become fertile in October and November of the following year at a time when the adult stags are rutting (Lincoln, 1971; Mitchell, 1973). The effect of season on the age of puberty is more apparent in animals that have a more extended mating period, and individuals born during the last part of the birth season show delayed maturity compared with animals born earlier (sheep: Skinner \& Rowson, 1968; Courot, 1971; ferret: Hammond, 1974; hare: Raczynski, 1964; Lincoln, 1974; several rodents : Brambell \& Hall, 1939; Bergstedt, 1965; Jewell, 1966; Newson, 1963; Sadleir, 1969; Worth et al., 1973).

The purpose of the present study is to describe some of the endocrine factors associated with delayed puberty in the male hare, Lepus europaeus.

\section{Materials and Methods}

Thirty-eight adult ( $>12$ months of age) and 56 young male hares were shot between January 1971 and October 1972 on arable land near Guestwich in Norfolk $\left(52^{\circ} 48^{\prime} \mathrm{N}, 0^{\circ} 59^{\prime} \mathrm{E}\right)$. Blood samples were taken into heparinized bottles within $5 \mathrm{~min}$ of death and stored on ice until the plasma was separated and frozen 2-4 hr later. Smears were prepared from the cut surface of the cauda epididymidis and stained with nigrosin-eosin. The testes, seminal vesicles plus prostate, and pituitary were removed within $15 \mathrm{~min}$, stored on dry ice, and later weighed. A single eye from each animal was fixed in formol saline and the lens later dried for age determination (Bröekhuizen, 1973). The testosterone content of the testes and blood plasma was measured by radioimmunoassay (Rowe $e t$ al., 1974), with a chromatographic separation being performed on the testicular tissue samples (Lincoln, 1974). 
Plasma LH concentrations were measured by means of a double-antibody radioimmunoassay with a sheep system (Niswender et al., 1968), with an antibody raised in a guinea-pig against purified rabbit LH. The NIH-LH-S13 preparation was used for standard dilutions and the sensitivity of the assay was $1.0 \mathrm{ng} / \mathrm{ml}$. Dilutions of rabbit plasma samples which had been shown to contain high

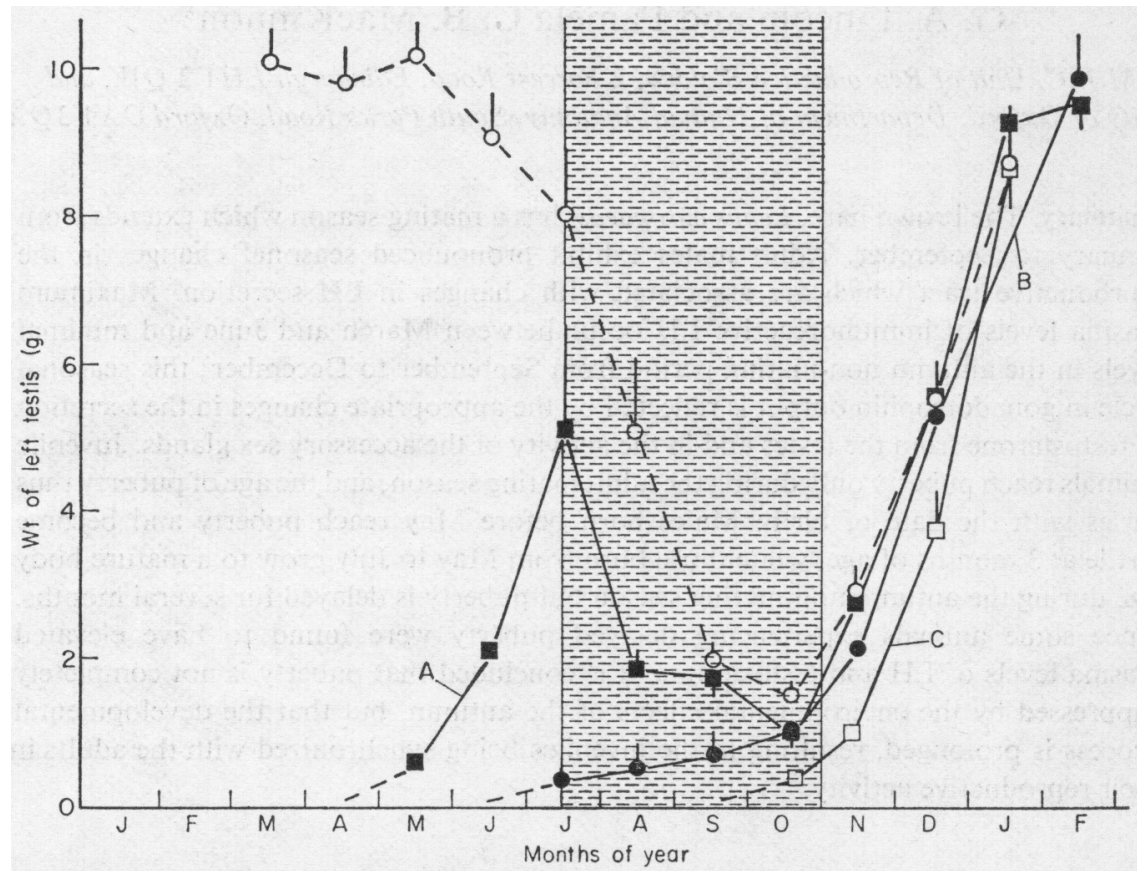

Text-fig. 1. Testis weights of young hares estimated to have been born before May (Group A, $\square$ ), between May and July (Group B, ๑) and after July (Group C, $\square$ ). Each point represents mean monthly weights based on 1-5 animals; the mean or mean \pm S.E.M. is indicated. The seasonal cycle in testis weights of adult hares is also shown $(O)$ and this is used to demarcate (shaded area) the environmental suppressive phase (see 'Discussion').

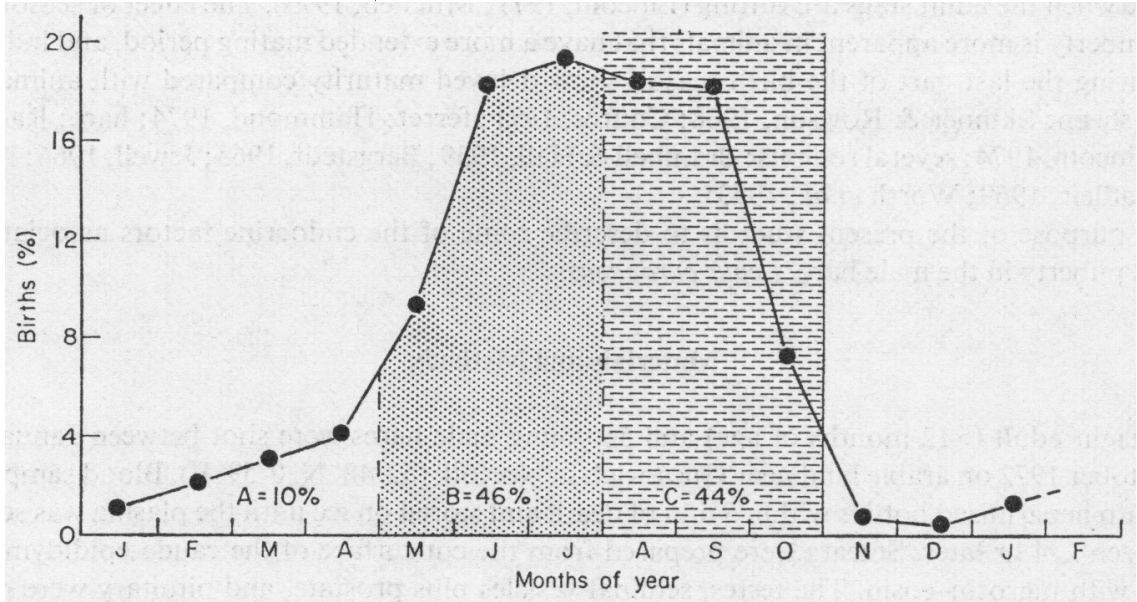

Text-fig. 2. Percentage of hares born in the different months of the year estimated from the age distribution of a sample of 551 hares under 12 months of age culled in February 1972 and 1974 at Six Mile Bottom in Cambridgeshire (for analysis, see Lincoln, 1974). Almost half of all births occur between May and July (Period B, stippled area) and these animals tend to reach a mature body size during the autumn period when the environment suppresses reproduction and puberty is delayed (hatched area). 
levels of LH were found to be parallel with the standard curve which on logit transformation gave a slope value of $-1 \cdot 18$. Duplicate samples obtained for the investigation were measured in a single assay and the intra-assay coefficient of variation was $5 \%$.

\section{Results}

\section{Grouping of animals}

Three groups of juvenile animals were recognized according to their estimated date of birth. (i) Group A contained animals which were born before May and showed a rapid development of the testes and reproductive tract at 2-3 months of age once they had achieved a body size of $2 \cdot 0-2 \cdot 4 \mathrm{~kg}$. The period of reproductive activity which supervened was quickly terminated after a few months when the juveniles experienced a regression of the testes in July and August similar to that of the adults (Text-fig. 1). (ii) Group B animals were born between May and July. They reached a mature body size at a time when environmental conditions were suppressing reproduction in the adults, and puberty was delayed for several months (Text-fig. 1). (iii) Group $\mathrm{C}$ animals were born late in the season, i.e. after July, and resembled those in Group A in showing rapid growth of the reproductive tract at the normal age of about 3 months which coincided with the beginning of the new breeding season for all animals (Text-fig. 1). Of the young hares in a wild population that survived until their first spring, about $10 \%$ were classified as Group A, $46 \%$ as Group B and $44 \%$ as Group C (Textfig. 2).

\section{Young hares born at different seasons}

The effect of season on the age of puberty was determined by comparing juveniles of Groups B and C (Text-fig. 3). In Group $\mathrm{C}$ animals maximum growth of the reproductive tract occurred between 3 and 6 months of age and spermatozoa were present in the epididymides at 4 months. In contrast, the animals of Group B showed only slow growth of the gonads and reproductive tract from 3 to 6 months and spermatozoa did not appear until normal development resumed after 6 months of age. The LH levels were slightly reduced in Group B animals during the period of delayed puberty.

\section{Young hares compared to adults}

The comparison of testis weight between young and old hares illustrated that the juveniles adopted the seasonal cycle of the adults (Text-fig. 1). More detailed comparison of young animals in delayed puberty (Group B) with adults, however, revealed some unexpected results (Text-fig. 4). During the autumn non-mating period from September to November the adult hares had minimal levels of LH in the blood plasma, small testes with a low content of testosterone, low peripheral levels of testosterone in the blood (19-200 $\mathrm{ng} / \mathrm{ml}$ ) and regressed accessory glands (Text-fig. 4). The juvenile hares at this time also had poorly developed reproductive tracts, but several of the young animals had unexpectedly high levels of plasma $\mathbf{L H}$ and elevated levels of peripheral and testicular testosterone (Text-figs $4 \mathrm{~d}$ and $\mathrm{f})$. The mean $( \pm$ S.E.) plasma testosterone concentration for adults in September, October and November was $182.7 \pm 98 \mathrm{ng} / 100 \mathrm{ml}(\mathrm{n}=9)$ compared with a mean level of $427.7 \pm 177 \mathrm{ng} / 100 \mathrm{ml}(\mathrm{n}=14)$ for the same period for Group B juveniles. Three juveniles shot in late October and November had higher plasma levels of testosterone $(1073-2241 \mathrm{ng} / 100 \mathrm{ml})$ than adults in the middle of the mating season, and yet had relatively small testes and undeveloped accessory glands.

\section{Discussion}

From June onwards the reproductive tract in the adult hare undergoes a regression which is apparently related to a reduction in gonadotrophin secretion, and from September to December the bucks are infertile (Lincoln, 1974). Since a delay in the timing of puberty only occurs in those juveniles which 

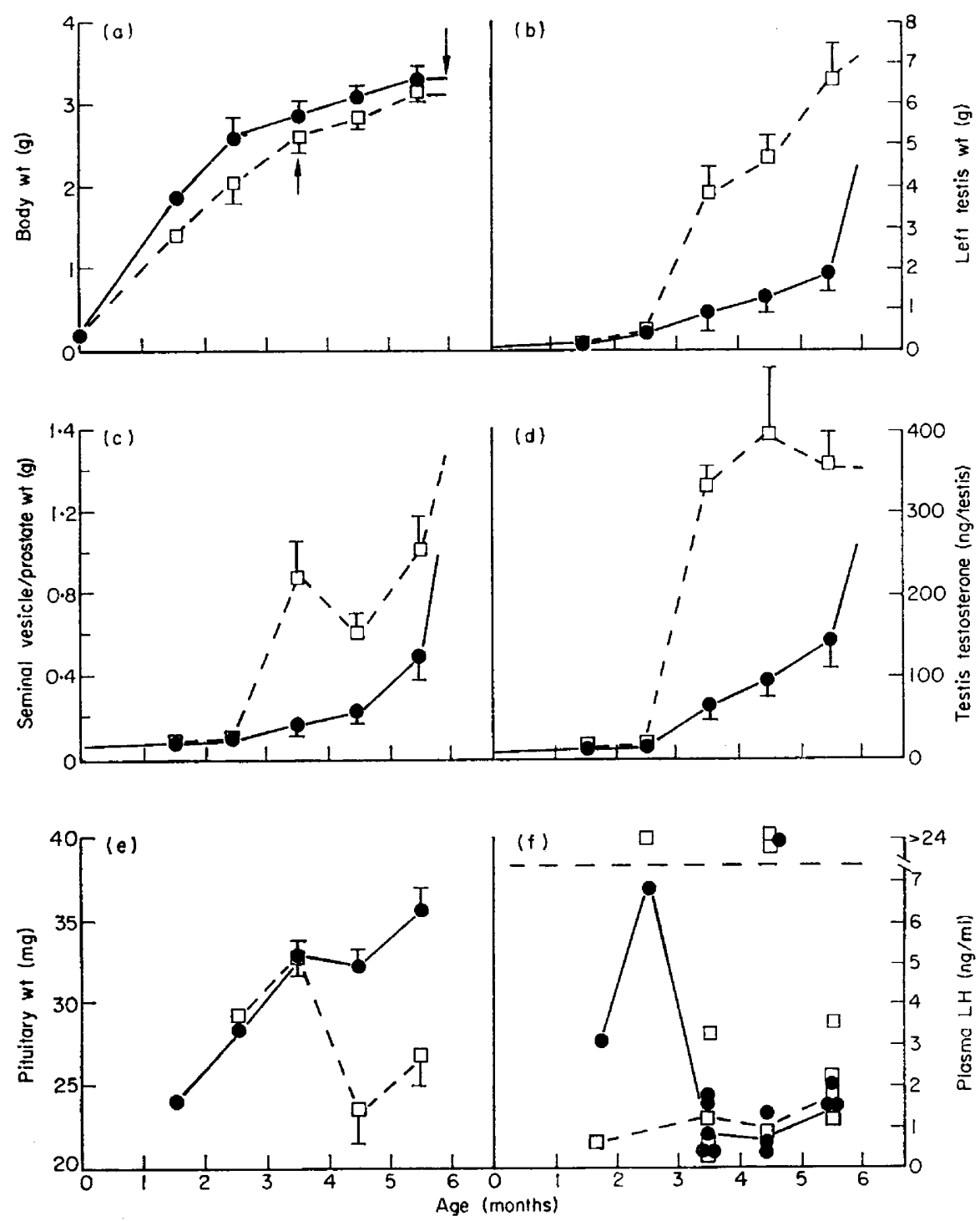

Text-fig. 3. Comparison of organ weights and hormone levels in juvenile hares born between May and July (Group B, $\bullet$ ) and those born between July and October (Group C, $\square$ ). Two-monthly means \pm S.E.M. are shown, except for Text-fig. 3(f) in which individual values for plasma LH are given with trend lines linking mean values that exclude the values above $24 \mathrm{ng} / \mathrm{ml}$ (very high values for LH are considered to result from the episodic release of $\mathbf{L H}$ ). Group B animals experience delayed puberty of some 3 months due to the environmental influence on reproduction; the age at which spermatozoa first appear in the epididymis is shown by arrows.

reach a mature size during the adult non-mating period in the autumn, it appears that the environmental factors which control the reproductive cycle in the adult also influence sexual development in the juvenile.

The changing pattern of daylength is probably the primary feature of the environment which dictates these changes, and this is supported by experimental studies on the closely related snow-shoe hare, Lepus americanus (Lyman, 1943; Davis \& Meyer, 1972). Apparently the conditions of decreasing daylength following the summer solstice in June suppress reproductive function in young and old 


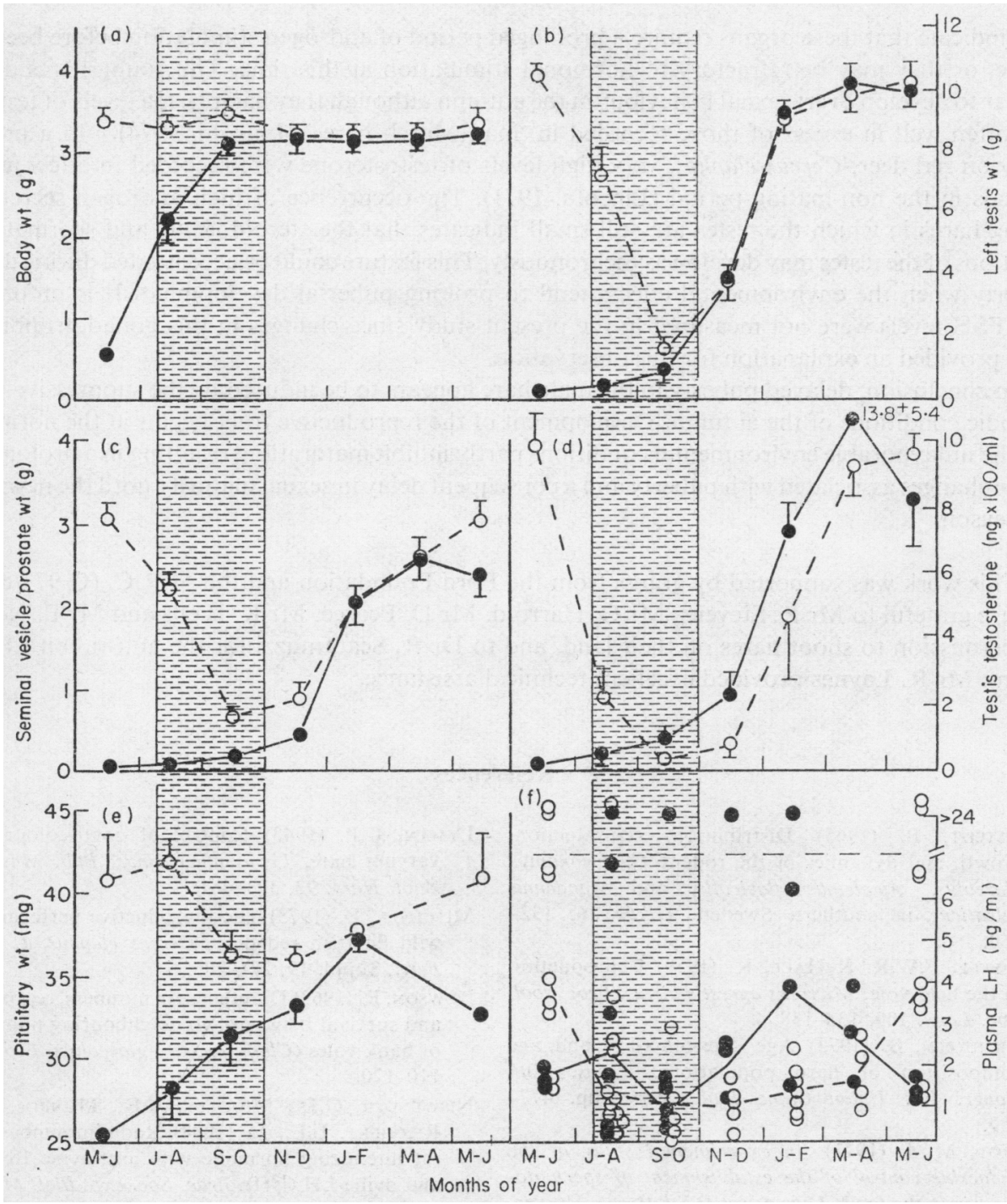

Text-fig. 4. Changes in organ weights and hormone levels in juvenile hares born between May and July (Group B, ) compared to seasonal changes in the adults $(O)$. Individual values for plasma LH concentration are depicted as in Text-fig. 3; other results are expressed as 2 -monthly means \pm S.E.M. The period denoted by the shaded area indicates the suppressive phase as in Text-fig. 1 .

hares. As the feeding conditions appear to be favourable during the early part of the non-mating period, a restriction in food supply is not considered to be important in dictating the timing of reproductive quiescence. In the present study, juvenile animals during delayed puberty grew faster than those born later and reaching puberty at the normal age (see Text-fig. 3a).

While the adult males show virtually no activity of the pituitary/gonad axis during the autumn, the juveniles reaching puberty at this time are not so completely inactive. After 3 months of age some development commences in the reproductive tract even during the unfavourable conditions of the autumn. By October and November some of these juveniles have begun to secrete large amounts of testosterone, although pubertal development is abnormal at this time since the youngsters still have small testes and undeveloped accessory glands. The immature condition of the accessory gland 
may indicate that these organs require a prolonged period of androgen stimulation before becoming active, or they may be refractory to hormonal stimulation at this time. The young hares did not appear to develop overt sexual behaviour in the autumn although they had plasma levels of testosterone often well in excess of those recorded in 'mad March hares' (Lincoln, 1974). In a previous study on red deer, Cervus elaphus, very high levels of testosterone were recorded in a few juvenile animals in the non-mating period (Lincoln, 1971). The occurrence of high androgen secretion in young hares in which the testes are still small indicates that the steroidogenic and spermatogenic functions of the testes may develop asynchronously. This feature could be accentuated during delayed puberty when the environmental effects tend to prolong pubertal development. It is unfortunate that FSH levels were not measured in the present study since changes in this gonadotrophin may have provided an explanation for this observation.

In conclusion, delayed puberty in the male hare appears to be induced by the suppressive photoperiodic conditions of the autumn. Development of the reproductive tract begins at the normal age but the unfavourable environmental conditions partly inhibit maturation, resulting in a prolongation of the changes associated with puberty and a consequent delay in sexual maturity until the new breeding season.

This work was supported by grants from the Ford Foundation and the M.R.C. (G 973/809/C). We are grateful to Mr R. Stevens, Mr G. Harrold, Mr D. Pearce, Mr K. Wells and Mr B. Norbury for permission to shoot hares on their land, and to Dr R. Scaramuzzi for the anti-rabbit LH antiserum. Mr R. Laynes provided excellent technical assistance.

\section{References}

BERGSTEDT, B. (1965) Distribution, reproduction, growth and dynamics of the rodent Clethrionomys glareolus, Apodemus flavicollis and Apodemus sylvaticus in southern Sweden. Oikos 16, 132160.

Brambell, F.W.R. \& Hall, K. (1939) Reproduction in the field vole, Microtus agrestis hirtus. Proc. zool. Soc. Lond. 109, 133-138.

Bröekhuizen, S. (1973) Age determination and age composition of hare populations. Trans. 10th Congr. Int. Union Game Biol., Paris, pp. 477489.

Courot, M.M. (1971) An experimental study of the endocrine control of the establishment of spermatogenesis in the lamb, Ovis aries. D.Sc. thesis, University of Paris.

DAVIS, G.J. \& MeYeR, R.K. (1972) The effect of daylength on pituitary FSH and LH and gonadal development of snowshoe hares. Biol. Reprod. 6, 264-269.

HAMmond, J., JR (1974) The Ferret-Some Observations on Photoperiod and Gonadal Activity, and their Role in Seasonal Pelt and Body Weight Changes. Heffer, Cambridge.

JEWELL, P.A. (1966) Breeding season and recruitment in some British mammals confined to small islands. Symp. zool. Soc. Lond. 15, 89-116.

Lincoln, G.A. (1971) Puberty in a seasonally breeding male, the red deer stag (Cervus elaphus). J. Reprod. Fert. 25, 41-54.

LinCOLN, G.A. (1974) Reproduction and 'March madness' in the Brown hare (Lepus europaeus). J. Zool., Lond. 174, 1-14.
Lyman, C.P. (1943) Control of coat colour in the varying hare, Lepus americanus. Bull. Mus. comp. Zool. Harv. 93, 393-461.

Mitchell, B. (1973) The reproductive performance of wild Scottish red deer, Cervus elaphus. J. Reprod. Fert., Suppl. 19, 271-285.

Newson, R. (1963) Differences in numbers, reproduction and survival between two neighbouring populations of bank voles (Clethrionomys glareolus). Ecology 44, 110-120.

Niswender, G.D., Midgley, A.R., Monroe, S.E. \& ReicherT, L.E., JR (1968) Radioimmunoassay for rat luteinizing hormone with anti-ovine $\mathrm{LH}$ serum and ovine LH $\left({ }^{131} \mathrm{I}\right)$. Proc. Soc. exp. Biol. Med. 128, 807-811.

RACZYNSKI, J. (1964) Studies of the European hare. V. Reproduction. Acta theriol. 9, 305-352.

Rowe, P.H., Lincoln, G.A., Racey, P.A., Lehane, J., Steprenson, M.J., Shenton, J.C. \& Glover, T.D. (1974) Temporal variations of testosterone levels in the peripheral blood plasma of men. $J$. Endocr. 61, 63-73.

SADLEIR, R.M.F.S. (1969) Ecology of Reproduction in Wild and Domestic Animals. Methuen, London.

SkInNER, J.D. \& Rowson, L.E.A. (1968) Puberty in Suffolk and cross-bred rams. J. Reprod. Fert. 16, 479-488.

Worth, R.W., Charlton, H.M. \& MacKinnon, P.C. (1973) Field and laboratory studies on the control of luteinizing hormone secretion and gonadal activity in the vole, Microtus agrestis. J. Reprod. Fert., Suppl. 19, 89-99. 